\title{
PENGEMBANGAN KAMUS PERBAIKAN BODI OTOMOTIF BERBASIS ANDROID UNTUK SISWA SEKOLAH MENENGAH KEJURUAN
}

\author{
Atmoko Putra Pratama ${ }^{1}$ dan Herminarto Sofyan ${ }^{2}$ \\ ${ }^{1}$ Program Pascasarjana Universitas Negeri Yogyakarta \\ ${ }^{2}$ Fakultas Teknik Universitas Negeri Yogyakarta \\ email: moko.putra91@gmail.com
}

\begin{abstract}
Abstrak
Tujuan penelitian ini adalah untuk menghasilkan kamus perbaikan bodi otomotif berbasis android yang layak dan efektif untuk penguasaan istilah asing autobody repair pada bahan ajaruntuk siswa sekolah menengah kejuruan (SMK). Penelitian pengembangan ini mengacu pada model Borg and Gall. Subjek penelitian adalah siswa SMK Kompetensi Keahlian Teknik Perbaikan Bodi Otomotif sebanyak 3 siswa untuk tahap uji coba lapangan awal, 6 siswa untuk uji coba lapangan utama dan 20 siswa untuk tahap uji coba lapangan operasional. Penilaian kelayakan produk berdasarkan penilaian ahli materi, ahli media, dan penilaian guru. Validasi instrumen ini melibatkan ahli pembelajaran teknik otomotif di sekolah kejuruan. Aspek penilaian kelayakan meliputi aspek kebenaran, keluasan, teori, format, dan konten. Hasil penelitian ini menunjukkan bahwa Kamus Perbaikan Bodi Otomotif berbasis android layak digunakan sebagai sumber belajar pada materi penguasaan istilah asing autobody repair untuk siswa SMK. Kamus yang dikembangkan efektif untuk meningkatkan pemahaman siswa terhadap istilah asing dengan peningkatan dalam kategori sedang. Penggunaan teknologi mendukung peningkatan proses dan kualitas pembelajaran di SMK.
\end{abstract}

Kata kunci: kamus, perbaikan bodi otomotif, android, penguasaan istilah

\section{DEVELOPING AUTOBODY REPAIR DICTIONARY BASED ON ANDROID FOR VOCATIONAL STUDENTS}

\begin{abstract}
The purpose of this study was to develop an android-based automotive body repair dictionary that is feasible and effective for mastering foreign terms autobody repair in teaching materials for vocational high school students. This development research refers to the Borg and Gall model. The research subjects were 3 students of Vocational High School for Automotive Body Repair Engineering Skills, as many as 3 students for the initial field trial phase, 6 students for the main field trial and 20 students for the operational field trial. The assessment of product feasibility based on the assessment of material experts, media experts, and teacher. The validation of this instrument involves learning experts in automotive engineering in vocational schools. The aspects of the feasibility assessment include aspects of validity, aspects of breadth, aspects of theory, aspects of format and aspects of content. The results of this study indicate that the Android-based Automotive Body Repair Dictionary is appropriate for use as a learning resource on mastering foreign terms related to autobody repair for vocational students. The dictionary developed is effective to improve students' understanding of foreign terms with an increase in the medium category. The use of technology supports the improvement of the learning process and quality in vocational level.
\end{abstract} Keywords: dictionary, automotive body repair, android, term mastery 


\section{PENDAHULUAN}

Kebutuhan industri terhadap lulusan Sekolah Menengah Kejuruan (SMK) perlu dipersiapkan dengan sebaik-baiknya melalui proses pembelajaran dan pendidikan yang baik. Tujuan dari Pendidikan Kejuruan telah tercantum pada UndangUndang Sistem Pendidikan Nasional (UUSPN) Nomor 20 Tahun 2003 pasal 15 yang menyatakan bahwa pendidikan menengah kejuruan memiliki tujuan dalam mempersiapkan siswanya untuk bekerja pada bidang-bidang tertentu (Depdiknas, 2003). Pendidikan diharapkan dapat mempersiapkan sumber daya manusianya untuk memiliki kemampuan berkomunikasi, menguasai ilmu pengetahuan dan teknologi (Yamtinah, Roemintoyo, \& Kartikasari, 2020). Hal ini diperkuat dengan pendapat yang disampaikan oleh Saputra dan Sukirno (2020) yang menyatakan bahwa siswa SMK perlu memiliki kesiapan kerja sebelum memasuki dunia kerja, baik siap secara afektif, kognitif dan psikomotorik. Siswa SMK hendaknya memiliki daya saing yang tinggi sebelum nantinya masuk ke dunia industri. Kemampuan siswa SMK untuk dapat bertahan dan berkembang di dunia industri salah satunya adalah kemampuan penyesuaian diri siswa terhadap perkembangan ilmu dan teknologi (Nugraha \& Wahyono, 2019)

Sejalan dengan kebutuhan industri Autobody Repair terhadap SDM yang berkualitas secara tidak langsung menuntut lulusan dari SMK kompetensi keahlian Teknik Perbaikan Bodi Otomotif untuk memiliki kompetensi sesuai dengan kebutuhan industri. Profil lulusan dunia industri yang bergerak di bidang Autobody Repair dan tingkat relevasinya dengan dunia pendidikan diketahui bahwa pengetahuan serta penguasaan komponen kendaraan sebelum melaksanakan perbaikan kendaraan menjadi dasar yang harus dikuasai oleh setiap lulusan (Yudantoko \& Arifin, 2016). Penguasaan dan pemahaman terhadap istilah-istilah komponen, prosedur hingga perawatan komponen menjadi hal yang sangat penting ketika nantinya terjun dalam dunia industri Autobody Repair, karena kesalahan sedikit saja menyebabkan terjadinya miskonsepsi makna yang ingin disampaikan.

Tujuan pembelajaran dan efektivitas pelaksanaan kegiatan pembelajaran perbaik-an bodi otomotif di SMK dapat tercapai dengan baik tidak terlepas dari proses yang dilaksanakan dan sumber belajar yang digunakan. Namun demikian, terdapat beberapa hal yang menjadi kendala dan permasalahan dalam proses pembelajaran sehingga berpengaruh terhadap penguasaan materi oleh siswa. Kurangnya pemahaman siswa terkait istilahistilah asing ini dikarenakan karakteristik materi yang melibatkan ingatan sehingga perlu pengulangan dalam menguasainya. Penggunaan buku pegangan dalam menyelesaikan job praktik, mengharuskan siswa membuka buku satu persatu untuk menyelesaikan permasalahan yang terdapat pada bahan ajar. Penguasaan bahan ajar menjadi hal yang sangat penting karena pemahaman terhadap suatu bahan ajar menjadi indikator sebuah keberhasilan dalam proses pembelajaran (Kristiyani, 2020).

Di sisi lain, siswa memiliki kecenderungan malas untuk membawa dan membaca buku yang banyak dan tebal. Siswa era saat ini yang merupakan anakanak generasi digital native lebih memilih browsing dengan menggunakan handphone ataupun laptop untuk menyelesaikan masalah yang dihadapi (Widyatmojo \& Muhtadi, 2017). Generasi digital native merupakan generasi yang lahir dan hidup di lingkungan digital sehingga telah mengenal komputer, internet, handphone, dan video 
game (Prensky, 2001). Dwiningsih, Sukarmin, Muchlis, dan Rahma (2018) juga menjelaskan bahwa generasi digital native atau sering disebut juga sebagai generasi $\mathrm{Z}$ merupakan generasi yang memiliki kemampuan dan keunggulan dalam pemanfaatan teknologi sebagai informasi dan komunikasi.

Permasalahan penguasaan siswa terhadap istilah-istilah asing salah satunya didukung oleh data hasil belajar aspek kognitif yang belum mencapai SKM (Skor Ketuntasan Minimum). Hasil belajar ini perlu diperbaiki selain agar memenuhi standar SKM tetapi juga untuk menunjukan tingkat penguasaan siswa terhadap materi yang diajarkan dalam proses pembelajaran. Seperti dikemukakan oleh Hamalik (Tohari, Mustaji, \& Bahri, 2019) bahwa hasil belajar merupakan sebuah indikator bertambahnya pengetahuan dan kompetensi melalui perubahan persepsi dan tingkah laku yang dimiliki oleh seseorang. Hasil belajar tergantung dari yang telah diketahui sebelumnya oleh siswa seperti konsep-konsep, tujuan, dan motivasi yang dipengaruhi interaksi secara terus menerus dengan bahan (resources) yang dipelajari. Hal ini menunjukan bahwa hasil belajar merupakan sebuah penilaian akhir terhadap proses dan pengenalan yang sudah dilakukan oleh seseorang secara berulangulang. Berdasarkan hal tersebut, potensi yang dapat digunakan sebagai solusi adalah dengan memberikan stimulus dan pengalaman belajar baru terhadap siswa yang terus melekat pada diri siswa. Hal ini didukung oleh pendapat dari Sudjana (2006, p. 22) yang menyatakan bahwa hasil belajar akan terus melekat pada diri siswa karena secara tidak langsung sudah menjadi bagian yang tidak terpisahkan pada kehidupan siswa yang belajar.

Potensi lain adalah pemanfaatan handphone sebagai sumber belajar.
Kecenderungan siswa generasi digital native lebih memilih untuk browsing dibandingkan dengan membaca buku. Pemanfaatan handphone ini didukung oleh jumlah kepemilikan handphone yang dimiliki hampir oleh seluruh siswa. Data tersebut diperkuat oleh pendapat Gifary dan Kurnia (2015) yang menyatakan bahwa Indonesia menduduki peringkat kelima daftar pengguna smartphone terbesar di dunia dimana populasi pengguna smartphone jenis Android mencapai lebih dari 1 miliar. Menurut Horwitz mengacu pada data dari wearesocial.sg menunjukan bahwa $112 \%$ penduduk di Indonesia menggunakan mobile device dengan jenis sistem operasi sebagian besarnya adalah sistem operasi Android (Triluqman, Mulyoto, \& Sutimin, 2018). Jumlah daftar pengguna smartphone di Indonesia tersebut didukung oleh penelitian dari Kementrian Informasi bersama dengan UNICEF yang mengelompokan kategori pengguna smartphone pada usia anakanak dan remaja di Indonesia mencapai 79,5\% (Heni, \& Mujahid, 2018). Jumlah pengguna smartphone berdasarkan tingkat pendidikan, hasil penelitian dari Puslitbang Aptika IKP Kominfo menunjukan 40,87\% pengguna $\mathrm{SD} ; 59,89 \%$ pengguna SMP; dan $79,56 \%$ pengguna SMA. Persentase pengguna untuk tingkat pendidikan SMA termasuk di dalamnya Sekolah Menengah Kejuruan memiliki persentase yang paling besar. Smartphone berplatfrom Android masih menjadi favorit karena memiliki sistem operasi Android yang bersifat open source. Android didefinisikan sebagai sebuah sistem operasi yang didesain secara open source yang dapat diunduh secara lengkap untuk perangkat seluler yang dilengkapi dengan sistem operasi, middleware, dan aplikasi utama berbasis Linux dan Java (Khanna, 2016). 
Smartphone menjadi sebuah platfrom yang berpotensi untuk dikembangkan secara khusus menjadi salah satu sumber belajar dalam mengatasi masalah belajar. Pengembangan terhadap potensi sumber belajar (resources) menurut AECT dikelompokan menjadi dua yaitu by design dan by utilization. Sumber belajar by design merupakan sumber belajar yang didesain dan dirancang secara khusus sebagai komponen sistem instruksional dalam memfasilitasi belajar yang bersifat formal, serta memiliki tujuan tertentu dan terarah. Sedangkan sumber belajar by utilization adalah sumber belajar yang tidak didesain secara khusus untuk kegiatan pembelajaran namun dapat dimanfaatkan untuk belajar (Maswan \& Muslimin, 2017, p. 30).

Berdasarkan permasalahan dan potensi dari proses pembelajaran teknik perbaikan bodi otomotif, maka perlu adanya pengembangan resources by design yang tidak tercetak dengan tampilan menarik yang dapat digunakan dan dimanfaatkan oleh siswa pada kapan saja dan dimana saja. Resources yang tepat untuk memfasilitasi hal tersebut adalah dictionary (kamus) berbasis Android. Dictionary berbasis Android merupakan electronic dictionary yang berfungsi untuk memfasilitasi siswa dalam menguasai dan memahami istilahistilah baru melalui perangkat handphone berbasis Android. Dictionary berbasis Android memungkinkan dan mendukung siswa untuk melakukan proses belajar secara berulang-ulang dimana saja, kapan saja secara mandiri.

Penggunaan dictionary yang berulangulang akan berdampak pada penguasaan terhadap suatu istilah, dengan demikian maka pengembangan resources dictionary berbasis Android merupakan sebuah solusi yang tepat dalam memfasilitasi siswa menguasai istilah-istilah pada
Autobody Repair. Hal ini sangat sesuai dengan definisi teknologi pendidikan menurut AECT 2008 yaitu studi dan etika praktik untuk memfasilitasi pembelajaran serta meningkatkan kinerja dengan cara menciptakan, menggunakan, dan mengelola proses dan sumber daya teknologi yang tepat (Januszewski, \& Molenda, 2008, p. $1)$.

Penggunaan resources dictionary dalam mendukung penguasaan istilahistilah dan penguasaan kosakata didukung oleh penelitian yang dilakukan oleh Amirian dan Heshmatifar (2013) terkait The Impact of Using Electronic Dictionary on Vocabulary Learning and Retention of Iranian EFL Learners terhadap 134 siswa di Iran yang menunjukan bahwa electronic dictionary merupakan alat pembelajaran yang efektif dalam meningkatkan penguasaan kosakata. Penelitian lain yang mendukung pengembangan ini dilakukan oleh Toghyani dan Salehi (2016) terkait Impact of Using Electronic Dictionary on Collocation Learning and Retention of Iranian EFL Learners dengan melakukan eksperimen pada 340 siswa dari 6 lembaga bahasa di Iran menunjukan hasil bahwa kelompok eksperimen menggunakan electronic dictionary secara signifikan memperoleh hasil belajar yang lebih baik dibandingkan dengan kelas kontrol.

Berdasarkan latar belakang yang telah dijabarkan sebelumnya, maka diperlukan pengembangan Kamus Perbaikan Bodi otomotif berbasis Android untuk penguasaan istilah asing Autobody Repair Pada Bahan Ajar Teknik Perbaikan Bodi Otomotif. Adapun tujuan penelitian ini adalah untuk mengetahui kelayakan dan keefektifan Kamus Perbaikan Bodi Otomotif berbasis android untuk penguasaan istilah asing Autobody repair pada bahan ajar teknik perbaikan bodi otomotif. 


\section{METODE}

Penelitian Research and Development dilaksanakan pada Tahun Ajaran 2018/2019 dengan subjek penelitian adalah Siswa kelas XI pada Kompetensi Keahlian Teknik Perbaikan Bodi Otomotif di SMK N 2 Depok Sleman. Prosedur pengembangan yang dilakukan dalam penelitian ini menggunakan model pengembangan Borg dan Gall. Terdapat 10 langkah menurut Borg dan Gall di antaranya adalah research and information collecting, planning, develop preliminary form of product, preliminary field testing, main product revision, main field testing, operational product revision, operational field testing, final product revision, dissemination \& implementation. Berikut ini adalah tahapan-tahapan yang dilakukan sesuai dengan model pengembangan Borg dan Gall (Mulyatiningsih, 2013, p. 163).

Pada tahapan research and information collecting merupakan kegiatan analisis awal terhadap kondisi pembelajaran di sekolah, karakteristik siswa, kemampuan awal siswa, tujuan dan kompetensi dasar yang dicapai oleh siswa. Tahapan selanjutnya adalah planning, tahapan ini meliputi pengumpulan berbagai referensi terkait pengembangan media, bahan ajar teknik perbaikan bodi otomotif. Pada tahapan ini juga dilakukan perumusan tujuan penyusunan media dan pendekatan yang digunakan dalam pengembangan media serta pengembangan storyboard.

Tahapan develop preliminary form of product merupakan pengembangan produk awal sesuai dengan desain perancangan desain yang telah disusun pada storyboard hingga menghasilkan produk awal aplikasi Kamus Perbaikan Bodi Otomotif berbasis Android. Pada tahapan ini pula dilakukan validasi terhadap rancangan produk oleh ahli media dan ahli materi, hal ini dilakukan guna mengetahui kelayakan dari rancangan produk yang dikembangkan dari berbagai aspek yaitu aspek media dan aspek materi.

Tahapan preliminary field testing merupakan uji coba lapangan awal. Uji coba ini dilakukan dalam skala kecil dengan melibatkan jumlah siswa yang terbatas yaitu 3 siswa yang dipilih secara acak. Selanjutnya siswa dipersilahkan untuk mengerjakan pretest yang berkaitan dengan materi perbaikan bodi otomotif dimana terdapat istilah-istilah asing mengenai body repair. Setelah melaksanakan pretest siswa diberikan perlakuan dengan menggunakan produk yang telah dikembangkan sebagai media belajar. Kemudian setelah adanya perlakuan siswa dipersilahkan untuk mengerjakan posttest dan mengisi angket respons siswa yang telah disediakan peneliti. Tahapan selanjutnya setelah mengetahui hasil dari uji coba lapangan awal adalah main product revision. Tahapan ini merupakan revisi awal berdasarkan hasil analisis yang dilakukan dari uji coba lapangan awal dan masukan yang diperoleh pada saat uji coba dilaksanakan.

Main field testing adalah tahapan uji lapangan utama. Pada tahapan ini melibatkan siswa kompetensi keahlian teknik perbaikan bodi otomotif dengan jumlah siswa yang lebih banyak dibandingkan sebelumnya, yaitu 6 siswa. Siswa tersebut dipilih secara acak untuk selanjutnya dilakukan tes kemampuan awal melalui pretest. Setelah pretest dilakukan, kemudian dilakukan perlakukan terhadap siswa tersebut dengan menggunakan media yang telah dikembangkan. Selanjutnya adalah melakukan posttest untuk mengetahui dampak terhadap perlakuan dan siswa diberikan angker respons siswa terhadap media yang dikembangkan. Tahapan selanjutnya adalah operational product revision, tahapan ini adalah melakukan perbaikan atau revisi berdasarkan hasil 
uji coba lapangan utama yang telah dilaksanakan sebelumnya.

Operational field testing adalah uji coba lapangan operasional. Uji ini melibatkan 20 siswa kompetensi keahlian teknik perbaikan bodi otomotif. Hampir sama dengan tahapan sebelumnya, siswa dipersilahkan untuk mengerjakan pretest terlebih dahulu guna mengetahui kemampuan awal dari 20 siswa tesebut. Selanjutnya siswa diberikan perlakuan dengan memanfaatkan media yang dikembangkan oleh peneliti. Setelah diberikan perlakuan siswa kembali dipersilahkan untuk melaksanakan posttest dan diberikan angket respons siswa terhadap media yang dikembangkan sebagai pertimbangan untuk melakukan final produk revision dari media yang dikembangkan.

Final product revision merupakan revisi produk tahap akhir terhadap media yang dikembangkan berdasarkan hasil ujicoba sebelumnya. Setelah dilakukan revisi akhir untuk selanjutnya produk dilakukan proses dissemination and implementation terhadap media yang telah dikembangkan yaitu Kamus Perbaikan Bodi Otomotif berbasis Android.

Instrumen yang digunakan untuk menganalisis kelayakan produk divalidasi dulu sebelum digunakan. Validasi instrumen ini melibatkan ahli pembelajaran teknik otomotifdi sekolah kejuruan. Aspek penilaian kelayakan meliputi aspek kebenaran, aspek keluasan, aspek teori, aspek format dan aspek konten dengan keseluruhan jumlah total indikator adalah 22 indikator penilaian. Berdasarkan hasil validasi instrumen pada tahap awal diketahui bahwa instrumen layak digunakan dengan revisi, kemudian peneliti melakukan perbaikan berdasarkan masukan yang diberikan oleh ahli untuk selanjutnya diajukan kembali dan diperoleh hasil bahwa instrumen penelitian layak digunakan untuk penelitian.
Data kelayakan terhadap media berupa data kualitatif dan kuantitatif. Data kualitatif adalah masukan dari validator dan reviewer/ guru yang dianalisis secara deskriptifmelalui pengelompokkan saran dan masukan. Selanjutnya, hasil telaah terhadap saran dan masukan tersebut digunakan sebagai dasar untuk memperbaiki produk media. Adapun analisis terhadap kelayakan media yang dikembangkan didasarkan pada hasil penilaian oleh ahli materi, ahli media dan penilaian guru. Hasil skor kuantitatif yang diperoleh diubah ke dalam data interval kemudian dikonversikan menjadi data kualitatif dengan menggunakan skala 5 . Skor rerata dari masing masing komponen dilakukan perhitungan dengan menggunakan rumus (1) yang dikemukakan oleh Usman dan Setyadi (2011).

$$
\bar{X}=\frac{\sum x}{N}
$$

Keterangan:

$\bar{X}$ : Rerata Skor Tiap Komponen

$\sum x:$ Jumlah Skor

$N$ : Jumlah Indikator yang dinilai

Data yang diperoleh diubah kedalam data kualitatif dengan menggunakan acuan konversi yang dikemukakan oleh Widoyoko (2009, p. 11) sebagai berikut.

Tabel 1

Konversi Skor Kuantitatif ke Kualitatif

\begin{tabular}{cl}
\hline \multicolumn{1}{c}{ Rentang } & Kategori \\
\hline$X>3,4$ & Sangat Layak (SL) \\
$2,8<X \leq 3,4$ & Layak (L) \\
$2,2<X \leq 2,8$ & Cukup (C) \\
$1,6<X \leq 2,2$ & Kurang Layak (KL) \\
$X \leq 1,6$ & Sangat Kurang Layak \\
& (SKL) \\
\hline
\end{tabular}

Produk yang telah divalidasi kemudian diuji efektivitas di SMK N 2 Depok, Sleman 
dengan melibatkan 29 siswa kelas XI Kompetensi Keahliah Teknik Perbaikan Bodi Otomotif. Uji coba efektivitas mencakup uji respons siswa dan eksperimen penggunaan media dalam pembelajaran. Uji respons siswa dilaksanakan melalui 2 tahapan uji yaitu uji coba lapangan awal dan uji coba lapangan utama. Adapun tahap eksperimen dilakukan sebagai dan uji coba lapangan operasional. Uji coba lapangan awal melibatkan 3 siswa yang dipilih secara random. Siswa dipersilahkan untuk menggunakan resources yang sebelumnya telah dilakukan validasi. Selanjutnya, dilaksanakan uji coba lapangan utama yang melibatkan 6 siswa teknik perbaikan otomotif yang dipilih secara acak dan dipersilahkan untuk menggunakan resources yang telah dikembangkan.

Setelah mengetahui respons siswa pada uji coba lapangan utama, selanjutnya dilaksanakan uji coba operasional yang melibatkan 20 siswa. Uji efektivitas pada tahap ini diukur berdasarkan peningkatan pemahaman siswa terhadap istilahistilah asing yang berkaitan dengan Body Repair melalui pretest-posttest dengan menggunakan desain eksperimen one group pretest-posttest design. Adapun desain ujicoba one group pretest-posttest design sesuai dengan yang disampaikan oleh Handari dan Sugianto (2019) (Tabel 2).

\section{Tabel 2}

One Group Pretest-Posttest Design

\begin{tabular}{ccc}
\hline $\begin{array}{c}\text { Pengukuran } \\
\text { (Pretest) }\end{array}$ & Perlakuan & $\begin{array}{c}\text { Pengukuran } \\
\text { (Posttest) }\end{array}$ \\
\hline $\mathrm{O}_{1}$ & $\mathrm{X}$ & $\mathrm{O}_{2}$ \\
\hline
\end{tabular}

Peningkatan hasil belajar siswa terhadap penguasaan istilah-istilah asing yang berkaitan dengan Body Repair dihitung menggunakan pengujian n-Gain menurut Hake (Munif, Susanto, \& Suslo, 2016) dengan rumus (2).

$$
g=\frac{\text { Spost-Spre }}{\text { Smaks-Spre }}
$$

Keterangan:

$g \quad$ : Skor gain yang dinormalisasi

Spost : Skor Posttest

Spre : Skor Pretest

$S_{\text {maks }}$ : Skor Maksimal

Hasil dari tinggi rendahnya gain yang dinormalisasi ( $N$-gain) kemudian diinterpretasikan ke dalam bentuk tabel nilai gain (Tabel 3).

Tabel 3

Kriteria n-Gain

\begin{tabular}{cc}
\hline Rentang Nilai & Kategori \\
\hline$(N$-gain $) \geq 0,7$ & Tinggi \\
$0,7>(N$-gain $) \geq 0,3$ & Sedang \\
$(N$-gain $)<0,3$ & Rendah \\
\hline
\end{tabular}

\section{HASIL PENELITIAN DAN PEMBAHASAN}

Penelitian pengembangan yang dilaksanakan bertujuan menghasilkan resources untuk penguasaan istilah-istilah asing pada bahan ajar Autobody Repair pada kompetensi keahlian Teknik Perbaikan Bodi Otomotif dan keefektifan dari produk resources yang dikembangkan. Pelaksanaan penelitian yang dilakukan terdiri dari serangkaian kegiatan yang tersusun secara sistematis sesuai dengan tahapan-tahapan model pengembangan menurut Borg and Gall.

Tahapan kegiatan awal yang dilaksanakan adalah analisis kebutuhan yang diperlukan sebelum melakukan perancangan sebuah resources. Analisis kebutuhan ini meliputi analisis terhadap karakteristik siswa, tujuan dan kompetensi yang hendak dicapai siswa, bahan ajar yang digunakan 
siswa dan kemampuan awal siswa. Teknik dan instrumen yang digunakan dalam pengumpulan data ini menggunakan nontest dan test. Non-test dilaksanakan dengan menggunakan teknik observasi, angket dan wawancara sedangkan tes dilaksanakan untuk mengukur kemampuan awal siswa dan kemampuan setelah dilaksanakan perlakuan melalui pretest dan posttest.

Hasil tes kemampuan awal siswa Teknik Perbaikan Bodi Otomotif melalui pretest diketahui bahwa dari 29 siswa kelas XI, sebanyak 70\% siswa belum memenuhi SKM (Skor Ketuntasan Minimum). Hal ini didukung oleh hasil wawancara kepada 10 siswa yang dipilih secara acak yang sebagian besar beranggapan pada materi yang diajarkan terdapat istilah-istilah yang belum sepenuhnya dikuasai dan dipahami sehingga menyulitkan untuk memahami materi yang sedang dipelajari. Pada saat guru memberikan kesempatan untuk bertanya diakui oleh beberapa siswa bahwa mereka merasa malu untuk bertanya, hal ini berdampak pada asumsi guru bahwa siswa sudah memahami materi tersebut ketika tidak ada yang bertanya. Selain itu, berdasarkan hasil observasi sumber belajar mandiri tercetak belum efektif dalam memberikan pemahaman terkait istilahistilah yang terdapat dalam Autobody Repair. Hal ini diperkuat oleh perilaku siswa era saat ini yang tergolong sebagai anak-anak generasi digital native memilih browsing memilih menggunakan handphone ataupun laptop untuk menyelesaikan masalah yang dihadapi.

Fenomena digital native ini menjadi sebuah potensi dalam menyelesaikan permasalahan pembelajaran yang terjadi. Potensi ini adalah pemanfaatan handphone sebagai sumber belajar. Hal tersebut dapat dilihat dari penjelasan sebelumnya dimana kecenderungan siswa yang memilih untuk browsing menggunakan handphone atau laptop dibandingkan dengan membaca buku dalam menyelesaikan sebuah permasalahan dalam Autobody Repair. Potensi ini didukung oleh kepemilikan handphone siswa yang mana keseluruhan siswa kelas XI teknik perbaikan bodi otomotif yang berjumlah 29 siswa, seluruhnya (100\%) memiliki smartphone dengan platform berbasis Android. Setelah diketahui potensi yang dapat dijadikan sebagai solusi pemecahan masalah, kemudian dilaksanakan pengembangan produk awal resources. Hasil dari pengembangan produk awal ini nantinya dilakukan validasi dan penilaian oleh ahli materi, ahli media dan penilaian oleh guru Teknik Perbaikan Bodi Otomotif.

Tahapan selanjutnya adalah pengembangan produk untuk menghasilkan produk awal Auto Body Repair Dictionary berbasis Android. Tahapan yang dilakukan diantaranya adalah adalah pembuatan storyboard, selecting data materi, pembuatan database, input data dan output data. Pembuatan storyboard merupakan blueprint Auto Body Repair Dictionary berbasis Android dan sebagai acuan awal untuk memproduksi sebuah produk. Storyboard berisikan konsep desain produk yang terdiri dari konsep audio, ukuran gambar ataupun audio, resolusi serta format file audio ataupun gambar, navigasi, tampilan awal, tampilan isi, tampilan latihan hingga tampilan penutup.

Selecting data kata-kata asing Auto Body Repair merupakan tahapan pengumpulan data kata-kata asing pada buku-buku baik modul, new step body, dan modul yang digunakan dalam pembelajaran perbaikan bodi otomotif. Pemilihan kata-kata asing yang akan dijadikan isi konten dalam resources Auto Body Repair Dictionary berbasis Android berfokus pada kata-kata yang terdapat pada 5 Kompetensi Dasar pada Kompetensi Keahlian Teknik 
Perbaikan Bodi Otomotif. Pembuatan database merupakan kelanjutan proses dari selecting data dengan memanfaatkan penggunaan MS. Excel untuk memudahkan pengurutan istilah-istilah asing Auto Body Repair sesuai dengan abjad dari A-Z dan input data ke dalam aplikasi nantinya. Pembuatan database dikatakan selesai apabila keseluruhan draft kata yang telah dikumpulkan masuk kedalam draft data secara urut.

Input data merupakan pengintegrasian database dengan aplikasi Android Studio dengan menggunakan aplikasi $D B$ Browser (SQLite). Hasil dari pengintegrasian database tersebut adalah file berformat SQLite dan dengan format file tersebut maka file terkait istilah-istilah asing Auto Body Repair sudah siap untuk dilakukan proses output data melalui Android Studio. Output data menjadi tahapan akhir dalam menghasilkan produk yang dikembangkan. Pada tahapan ini database SQLite yang telah terintegrasi ke dalam Android Studio selanjutnya dilakukan proses output data sehingga menghasilkan file Auto Body Repair Dictionary.apk berformat APK. File APK berbasis aplikasi inilah yang nantinya dapat digunakan pada perangkat smartphone Android dengan cara diinstal seperti pada penginstalan aplikasi smartphone pada umumnya.

Produk yang telah dikembangkan dilakukan validasi oleh ahli materi. Hasil validasi oleh ahli materi dilakukan guna mengetahui kelayakan dan kualitas media yang dikembangkan dari aspek kurikulum, aspek penyajian isi, aspek tata bahasa dan aspek keterlaksanaan. Gambar 1 menyajikan hasil yang diperoleh berdasarkan hasil validasi oleh ahli materi.

Rerata hasil uji kelayakan oleh ahli materi diperoleh skor 3,38. Skor tersebut menunjukan bahwa kualitas media yang dikembangakan berdasarkan aspek materi termasuk dalam kategori layak untuk digunakan dalam memfasilitasi siswa untuk menguasai istilah-istilah asing pada mata pelajaran Autobody Repair.

Hasil penilaian media oleh ahli media dilaksanakan guna mengetahui kelayakan media dari sisi media. Adapun aspek yang dinilai oleh ahli media di antaranya adalah terkait aspek kualitas tampilan, rekayasa perangkat lunak, interface, reusable, maintainable, dan compatibility. Gambar

Gambar 1. Grafik Skor Validasi Ahli Materi

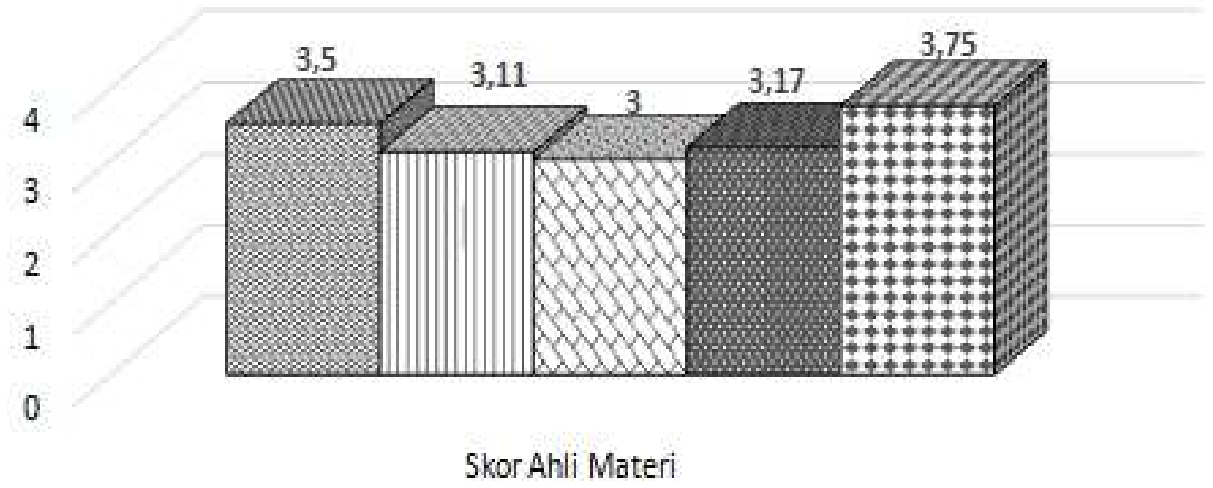

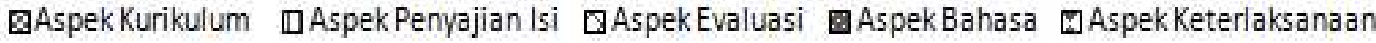


2 menyajikan skor yang diperoleh pada masing-masing aspek.

Rerata hasil uji kelayakan oleh Ahli Media diperoleh skor 3,44. Rerata skor tersebut menunjukan bahwa media yang dikembangkan berdasarkan penilaian oleh ahli media termasuk dalam kategori sangat layak.

Penilaian media oleh guru melibatkan tiga guru teknik perbaikan bodi otomotif. Hasil dari penilaian guru terhadap kelayakan media menunjukan hasil yang positif.
Penilaian ini meliputi adalah aspek kurikulum, penyajian isi Kamus Perbaikan Bodi Otomotif, tata bahasa, keterlaksanaan, dan rekayasa perangkat lunak. Skor hasil penilaian media oleh guru pada kompetensi keahlian teknik perbaikan bodi otomotif dapat dilihat pada Gambar 3.

Rerata keseluruhan hasil penilaian oleh guru memperoleh skor 3,58. Skor ini menunjukkan bahwa resources yang dikembangkan berdasarkan penilaian guru termasuk dalam kategori sangat layak

Gambar 2. Grafik Skor Validasi Ahli Media

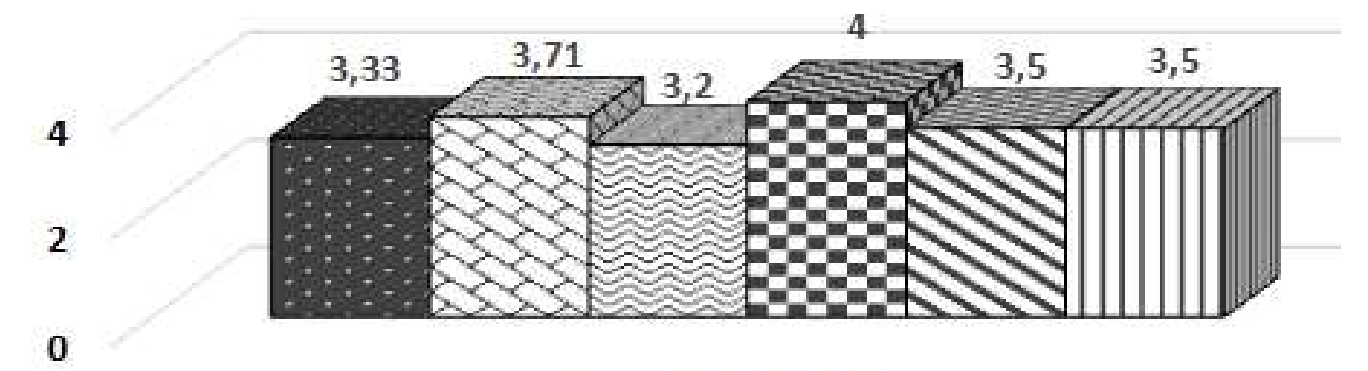

Aspek Tampilan

Aspek Rekayasa Perangkat Lunak

Aspek Interface

Bspek Reusable

Aspek Maintainable

II Aspek Compatibility

Gambar 3. Grafik Skor Penilaian Guru

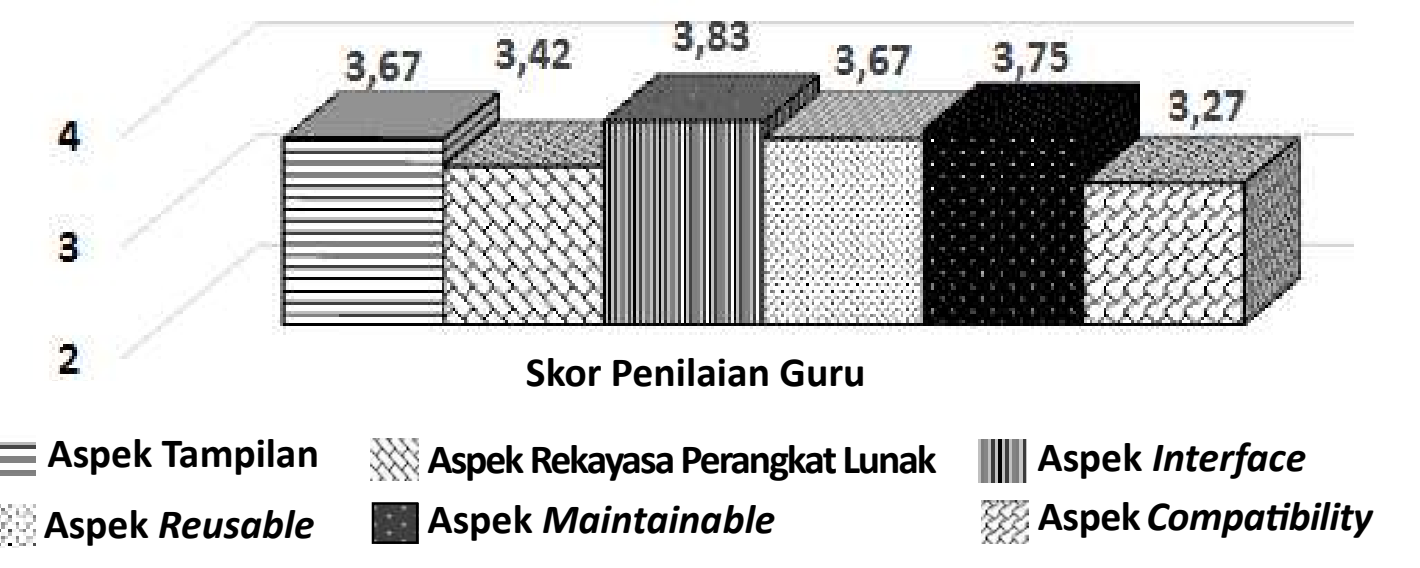


untuk digunakan oleh siswa sebagai upaya meningkatkan penguasaan istilah-istilah asing Autobody Repair pada bahan ajar teknik perbaikan bodi otomotif.

Hasil keseluruhan penilaian resources yang dikembangkan menurut para ahli materi, ahli media, dan guru memperoleh skor rerata 3,47 (kategori sangat layak). Hasil keseluruhan penilaian oleh ahli materi, ahli media dan guru disajikan pada Tabel 4.

Setelah dilaksanakan proses validasi terhadap resources oleh para ahli dan guru, selanjutnya adalah melakukan uji respons siswa. Uji respons siswa yang dilaksanakan melalui 3 tahapan uji yaitu uji coba lapangan awal, uji coba lapangan utama dan uji coba lapangan operasional. Pada uji coba respons siswa terdapat 3 aspek yang dinilai yaitu aspek kualitas tampilan, keterlaksanan, dan rekayasa perangkat lunak.

Hasil respons siswa pada uji coba lapangan awal diperoleh skor 3,33. Skor ini menunjukan bahwa respons siswa pada uji coba lapangan awal termasuk dalam kategori layak. Selanjutnya, dilaksanakan uji coba lapangan utama yang melibatkan 6 siswa teknik perbaikan otomotif yang dipilih secara acak dan dipersilahkan untuk menggunakan resources yang telah dikembangkan. Skor yang diperoleh pada uji coba lapangan utama ini adalah 3,46. Hasil ini menunjukan bahwa respons siswa pada uji coba lapangan utama termasuk dalam kategori sangat layak.
Setelah mengetahui respons siswa pada uji coba lapangan utama, selanjutnya dilaksanakan uji coba operasional yang melibatkan 20 siswa. Hasil uji coba lapangan operasional memperoleh skor 3,48 sehingga termasuk dalam kategori sangat layak. Rangkuman hasil respons siswa secara keseluruhan disajikan pada Gambar 4.

Rerata keseluruhan uji respons siswa yang meliputi uji coba lapangan awal, uji coba lapangan utama dan uji coba lapangan operasional diperoleh skor 3,43. Skor tersebut menunjukan bahwa resources yang dikembangkan berdasarkan uji respons siswa termasuk dalam kategori sangat layak.

Kefektifan produk yang dikembangkan diukur berdasarkan peningkatan aspek kognitif yang dimiliki siswa sebelum diberikan perlakukan melalui pretest dan setelah diberikan perlakukan melalui pelaksanaan posttest. Rerata hasil belajar pretest yang dilaksanakan memperoleh skor 70,76 dengan klasifikasi hasil kognitif termasuk dalam kategori baik. Setelah diberikan perlakuan dengan memberikan treatment dan resources yang telah dikembangkan sebagai media penguasaan istilah-istilah asing Autobody Repair, kemudian dilaksanakan posttest. Hasil posttest siswa diperoleh skor rerata 83,03 dengan klasifikasi hasil kognitif termasuk dalam kategori baik sekali.

Analisis peningkatan hasil belajar kognitif pretest dan posttest dianalisis

Tabel 4

Rerata Penilaian Ahli \& Guru

\begin{tabular}{lcc}
\hline \multicolumn{1}{c}{ Penilaian Ahli \& Guru } & Skor & Kategori Penilaian \\
\hline Ahli Materi & 3,38 & Layak \\
Ahli Media & 3,44 & Sangat Layak \\
Guru & 3,58 & Sangat Layak \\
\hline Rerata Skor Keseluruhan & 3,47 & Sangat Layak \\
\hline
\end{tabular}


Gambar 4. Grafik Hasil Uji Respon Siswa

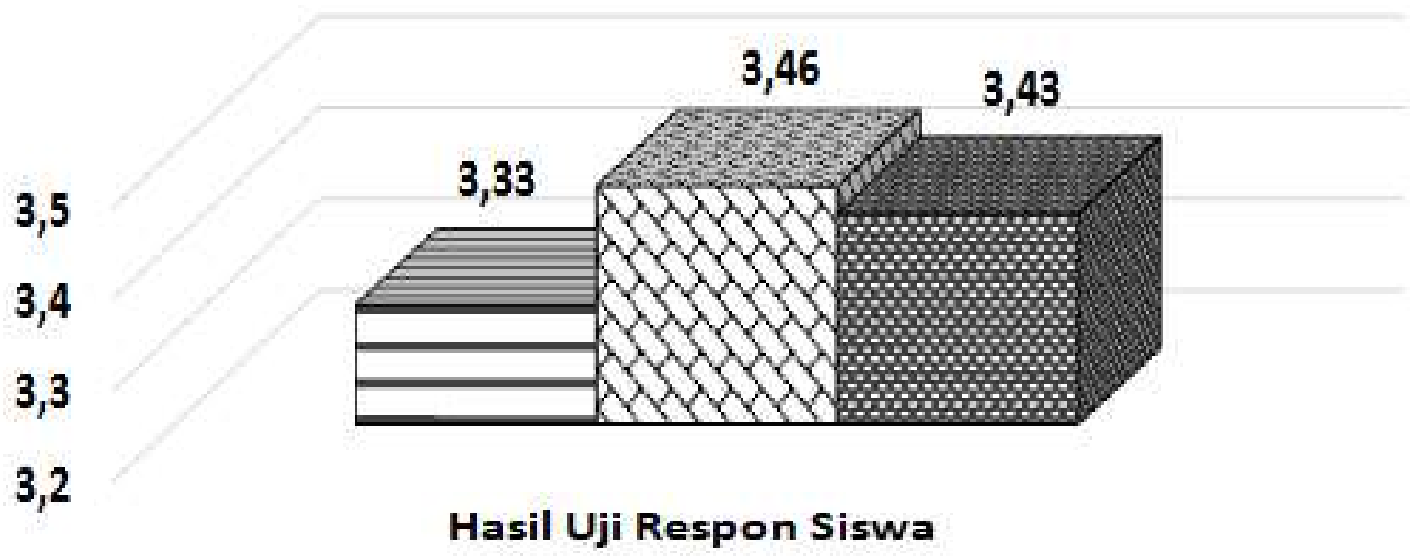

\section{日Uji Awal $\nabla$ Uji Utama 圈Uji Operasional}

dengan menggunakan rumus $\mathrm{N}$-Gain (Tabel 5). Berdasarkan hasil analisis terhadap peningkatan hasil belajar aspek kognitif melalui pretest dan posttest maka dapat disimpulkan bahwa resources Kamus Perbaikan Bodi Otomotif berbasis Android merupakan media yang efektif dalam meningkatkan penguasaan istilah asing Autobody Repair pada bahan ajar Perbaikan Bodi Otomotif. Peningkatan hasil belajar aspek kognitif tersebut didukung dengan hasil analisis $\mathrm{N}$-Gain yang memperoleh skor 0,42 yang termasuk dalam kategori sedang.

Penelitian pengembangan yang dilakukan menunjukkan peran teknologi pembelajaran untuk memfasilitasi siswa menguasai istilah-istilah pada bahan ajar perbaikan bodi otomotif. Hal ini merupakan sebuah upaya yang dilakukan untuk menuntaskan masalah belajar dengan mengacu pada definisi Teknologi Pendidikan menurut AECT 2008 yaitu melalui proses penciptaan, pemanfaatan dan pengelolaan proses dan resources yang sesuai dengan analisis kebutuhan yang dilaksanakan.

Hal tersebut juga diperkuat oleh pendapat Reigult dan Merril (Degeng, 2013 , p. 12) yang menyatakan bahwa dalam proses perancangan pembelajaran yang tepat sehingga siswa dapat mencapai tujuan pembelajaran maka perlu dilakukan analisis terhadap variable kondisi yang meliputi karaktertik siswa, karakteristik bidang studi dan kendala yang dihadapi. Analisis tersebut telah dilaksanakan dalam proses pengembangan produk resources

Tabel 5

Uji N-Gain Hasil Belajar 29 Siswa

\begin{tabular}{cccc}
\hline Pretest & Posttest & Gain Score & Kategori $N$-Gain \\
\hline 70,76 & 83,03 & 0,42 & Sedang \\
\hline
\end{tabular}


Kamus Perbaikan Bodi Otomotif berbasis Android.

Hasil uji efektivitas media dalam meningkatkan penguasaan istilah pada bahan ajar teknik perbaikan bodi otomotif memiliki relevansi dengan pendapat yang disampaikan oleh Indriastuti (2017, p. 54) yang berpendapat bahwa pemanfaatan media (resources) memiliki tujuan agar siswa dapat memahami materi lebih mudah, lebih antusias dan kualitas belajar dapat lebih ditingkatkan. Hal ini juga diperkuat oleh penelitian yang dilakukan oleh Heflin, Shewmaker, dan Nguyen (2017) terkait Impact of Mobile Technology on Student Attitudes, Engagement, and Learning yang menunjukan bahwa pembelajaran yang memanfaatkan perangkat mobile sebagai resources memberikan dampak yang positif terhadap peningkatan pemahaman siswa dalam melaksanakan sebuah proses pembelajaran.

\section{SIMPULAN}

Hasil Pengembangan Kamus Perbaikan Bodi Otomotif berbasis Android merupakan media yang layak untuk meningkatkan penguasaan istilah-istilah asing Autobody Repair pada bahan ajar teknik perbaikan bodi otomotif. Hal tersebut dikarenakan resources yang dikembangkan telah divalidasi oleh ahli materi, ahli media dan dilakukan penilaian oleh guru. Hasil penilaian para ahli dan guru memperoleh rerata skor penilaian 3,47. Rerata skor tersebut berdasarkan kriteria penilaian termasuk dalam kategori sangat layak. Keefektifan ini dapat dilihat dari peningkatan hasil belajar aspek kognitif sebelum diberikan perlakukan (pretest) dan setelah diberikan perlakukan (posttest). Hasil belajar yang diperoleh berdasarkan pretest yang dilaksanakan memperoleh nilai 70,76 setelah diberikan pelakuan dan dilaksanakan posttest diperoleh nilai 83,03.
Peningkatan hasil belajar sebelum dan setelah diberikan perlakuan termasuk dalam kategori sedang dengan skor $N$-Gain 0,42. Berdasarkan hasil dan pembahasan yang telah disampaikan sebelumnya, adapun saran untuk penelitian selanjutnya adalah pengembangan ini dapat dikembangkan pada platform handphone lain selain android dan dilakukan penelitian dalam skala yang lebih luas.

\section{DAFTAR PUSTAKA}

Amirian, S., \& Heshmatifar, Z. (2013). The impact of using electronic dictionary on vocabulary learning and retention of Iranian EFL learners. International Journal of Research Studies in Educational Technology, 2(1), 35-44.

Degeng, N. S. (2013). Ilmu pembelajaran. Bandung: Aras Media.

Depdiknas. (2003). Undang-undang Republik Indonesia Nomor 20 Tahun 2003 Tentang Sistem Pendidikan Nasional. Jakarta: Depdiknas.

Dwiningsih, K., Sukarmin, Muchlis, \& Rahma, P. T. (2018). Pengembangan media pembelajaran kimia menggunakan media laboratorium virtual berdasarkan paradigma pembelajaran di era global. Kwangsan: Jurnal Teknologi Pendidikan, 6(2), 156176. http://dx.doi.org/10.31800/jtp. kw.v6n2.p156--176.

Gifary, S., \& Kurnia, I. (2015). Intensitas penggunaan smartphone terhadap perilaku komunikasi. Jurnal Sosiateknologi, 14(2), 170.

Handari, T. L., \& Sugianto, H. S. (2019). Pengembangan modul pembelajaran berbentuk pop-up dan smash book materi sifat cahaya bagi siswa penyandang disabilitas rungu. Unnes Physics Education Journal, 8(1), 9-15.

Heflin, H., Shewmaker, J., \& Nguyen, J. (2017). Impact of mobile technology 
on student attitudes, engagement, and learning. Computers \& Education, 107, 91-99. https://doi.org/10.1016/j. compedu.2017.01.006.

Heni, \& Mujahid, A. J. (2018). Pengaruh penggunaan smartphone terhadap perkembangan personal sosial anak usia prasekolah. Jurnal Keperawatan Silampari (JKS), 2(1), 330-334.

Indriastuti, F. (2017). Kontribusi pemanfaatan media audio aksi terhadap pengembangan kemampun berbahasa sejak dini. Kwangsan: Jurnal Teknologi Pendidikan, 5(1), 51-65. Diunduh dari https://doi.org/10.31800/jtp.kw.v5n1. p51--63.

Januszewski, A., \& Molenda, M. (2008). Educational technology: A Definition With commentary. New York: Lawrence Erlbaum Associates.

Khanna, P. (2016). Google android operating system: A review. International Journal of Computer Applications, 147(4), 26-29.

Kristiyani, A. (2020). Pengembangan buku referensi menulis faktual berbasis multiliterasi. Jurnal Kependidikan : Penelitian Inovasi Pembelajaran, 4(1), 177-184. Diunduh dari https://doi. org/10.21831/jk.v4i1.30724.

Maswan, \& Muslimin, K. (2017). Teknologi pendidikan: Penerapan pembelajaran yang sistematis. Yogyakarta: Pustaka Pelajar.

Mulyatiningsih, E. (2013). Metode penelitian terapan bidang pendidikan. Bandung: Alfabeta.

Munif, A., Susanto, H., \& Susilo. (2016). Pengembangan bahan ajar audio berbasis inkuiri berbantuan alat peraga pada materi gerak untuk anak tunanetra kelas VII SMP/MTs LB. Unnes Physics Education Journal, 5(3), 1-11.

Nugraha, C. A., \& Wahyono, S. B. (2019). Pengembangan multimedia pembelajaran interaktif untuk ranah psikomotorik siswa Sekolah Menegah Kejuruan. Jurnal Kependidikan : Penelitian Inovasi Pembelajaran, 3(2), 220-234.

Prensky, M. (2001). Digital natives, digital immigrants. From On the Horizon. $M C B$ University Press, 9(5), 1-6.

Saputra, B. D., \& Sukirno. (2020). Kesiapan kerja siswa program akuntansi pada Sekolah Menengah Kejuruan. Jurnal Kependidikan : Penelitian Inovasi Pembelajaran, 4(1), 139-151. https:// doi.org/10.21831/jk.v4i1.24651.

Sudjana, N. (2006). Penilaian hasil proses belajar mengajar. Bandung: Remaja Rosdakarya.

Toghyani, Z., \& Salehi, H. (2016). Impact of using electronic dictionary on collocation learning and retention of Iranian EFL learners. International Journal of English Language and Literature Studies, 5(1), 55-65.

Tohari, H., Mustaji, \& Bahri, B. S. (2019). Pengaruh penggunaan youtube terhadap motivasi belajar dan hasil belajar mahasiswa. Kwangsan: Jurnal Teknologi Pendidikan, 7(1), 1-13. http://dx.doi.org/10.31800/jtp. kw.v7n1.p1--13.

Triluqman, H., Mulyoto, \& Sutimin, L. A. (2018). Pengembangan model aplikasi simulator kamera video berbasis android untuk mata kuliah sinematografi pembelajaran. TEKNODIKA: Jurnal Penelitian Teknologi Pendidikan, 16(2), 7-16. Diunduh dari http://jurnal.fkip.uns. ac.id/teknodika.

Usman, H., \& Setyadi, P. (2011). Metodologi penelitian sosial. Jakarta: Bumi Aksara.

Widoyoko, E. P. (2009). Evaluasi program pembelajaran. Yogyakarta: Pustaka Pelajar. 
Widyatmojo, G., \& Muhtadi, A. (2017). Pengembangan multimedia pembelajaran interaktif berbentuk game untuk menstimulasi aspek kognitif dan bahasa anak TK. Jurnal Inovasi Teknologi Pendidikan, 4(1). Diunduh dari https://doi.org/10.21831/ jitp.v4i1.10194.

Yamtinah, S., Roemintoyo, \& Kartikasari, A. (2020). Pengembangan buku ajar ilmu pengetahuan alam berbasis sains teknologi masyarakat. Jurnal Kependidikan: Penelitian Inovasi Pembelajaran, 4(1), 1-14.

Yudantoko, A., \& Arifin, Z. (2016). Profil kompetensi dunia kerja bidang perbaikan bodi otomotif dan tingkat relevansinya dengan dunia pendidikan. Jurnal Pendidikan Vokasi, 6(2), 127142. Diunduh dari http://journal.uny. ac.id/index.php/jpv. 